\title{
A STUDY ON KINETIC AND THERMODYNAMIC ADSORPTION OF FLUORIDE FROM AQUEOUS SOLUTION ONTO ALUMINIUM HYDROXIDE COATED RICE HUSK ASH
}

\author{
Tran Ngoc Tuyen ${ }^{1}$, Nguyen Duc Vu Quyen ${ }^{1}$, Ho Van Minh Hai ${ }^{1}$, \\ Tran Ngoc Quang ${ }^{2}$, Hoang Trong $\mathrm{Sy}^{3}$, Nguyen Trong Liem ${ }^{4}$ \\ ${ }^{I}$ Department of Chemistry, Hue University of Sciences, 77 Nguyen Hue Str, Hue city \\ ${ }^{2}$ Department of Environmental Science, Hue University of Sciences, 77 Nguyen Hue Str., Hue \\ ${ }^{3}$ Hue University of Medicine and Pharmacy, 06 Ngo Quyen Str, Hue city \\ ${ }^{4}$ Medical Center, Ninhhoa district, Khanhhoa province \\ *Email: trntuyen@gmail.com
}

Received: 20 January 2016; Accepted for publication: 2 April 2016

\begin{abstract}
The fluoride adsorption on aluminum hydroxide coated rice husk ash material ( $\left.\mathrm{RHA} / \mathrm{Al}(\mathrm{OH})_{3}\right)$ was demonstrated in this study. The isothermal data indicated that the Langmuir model well described the adsorption system with the maximum monolayer adsorption capacity of $8.2 \mathrm{mg} . \mathrm{g}^{-1}$. The kinetic results revealed that the pseudo-second-order rate model fitted the experiments data better than the pseudo-first-order one. Furthermore, the adsorption of fluoride onto this material may be the chemical adsorption. Thermodynamic parameters $\left(\Delta \mathrm{G}^{\mathrm{o}}\right.$ and $\left.\Delta \mathrm{H}^{\mathrm{o}}\right)$ in the range of temperature from 30 to $70{ }^{\circ} \mathrm{C}$ showed that the adsorption was a spontaneous and an endothermic process. $\mathrm{RHA} / \mathrm{Al}(\mathrm{OH})_{3}$ could be used for well-treatment of fluoride contaminated well-water sampling in Ninhhoa district (Khanhhoa province). With the initial content of fluoride of $10.1 \mathrm{mg} . \mathrm{L}^{-1}$ and after 2 hours of treating with the dose of $4.0 \div 7.0 \mathrm{~g} . \mathrm{L}^{-1}$, the concentration of fluoride in the samples decreased to $0.5 \div 1.5 \mathrm{~g} . \mathrm{L}^{-1}$, that met acceptable limit of WHO.
\end{abstract}

Keywords: aluminium hydroxide coated rice husk ash, adsorption, fluoride.

\section{INTRODUCTION}

With human and animals body, fluorine is an integral element which plays the role of regulating the metabolism of calcium and phosphorus. It is necessary for the development of teeth and bone, the formation of teeth's tusk and enamel. When we lack of fluorine, our teeth will be decay and the bones will be spongy. However, if fluoride concentration exceeds acceptable limit $\left(1.5 \mathrm{mg} . \mathrm{L}^{-1}\right)$, the dental fluorosis will appear with main symptoms are that: teeth appearance is marred by discoloration or brown markings and break easily. Besides, the redundancy of fluoride in human body can make the bone weak, get out of shape, break easily, 
damage to thyroid gland, endocrine, brain... Nowadays, the fluorosis appears widely in over 25 countries and about 62 millions people catch this disease, especially, in Bangladesh, China, Mongolia India... [1]. In Vietnam, fluoride contaminated well-water (3 to $14 \mathrm{mg} . \mathrm{L}^{-1}$ ) results to the fluorosis widespread in Khanhhoa, Phuyen, Quangnam, Thaibinh provinces... [2]. So, the study on the removal of fluoride from running water is an urgent problem. One of methods using for treatment of fluoride interested most is using by sorbents such as hydroxyapatite [3], kaoline [4] or red mud [5] because of its high effect in reality.

In previous paper, the preparation of $\operatorname{RHA} / \mathrm{Al}(\mathrm{OH})_{3}$ was studied. The obtained material exhibited a large amount of amorphous silica and activated carbon with fine-grained particles, high porosity and it well adsorbs fluoride.

In this paper, isothermal, kinetic and thermodynamic results of the adsorption of fluoride onto this material were demonstrated.

\section{EXPERIMENTS}

\subsection{Adsorbent}

$\mathrm{RHA} / \mathrm{Al}(\mathrm{OH})_{3}$ was prepared from rice husk ash and $\mathrm{Al}^{3+}$ solution [6]. Rice husk was treated by $1 \mathrm{M} \mathrm{HCl}$ solution for 24 hours after being burned at $700{ }^{\circ} \mathrm{C}$ for 60 minutes. Rice husk ash (RHA) was obtained after being washed by deionized water and dried at $100{ }^{\circ} \mathrm{C}$. The mixture containing RHA and $0.1 \mathrm{M} \mathrm{Al}^{3+}$ solution was adjusted to the $\mathrm{pH}$ of $5 \div 6$ and stirred for 30 minutes. The content of $\mathrm{Al}_{2} \mathrm{O}_{3}$ in obtained material was $20 \%$. $\mathrm{Al}(\mathrm{OH})_{3}$ would be precipitated and dispersed on the surface of RHA particles. The solid product was washed and dried at 100 ${ }^{\circ} \mathrm{C}$.

The solutions of fluoride were prepared from $\mathrm{NaF}$ (PA, Sigma-Aldrich). The concentration of fluoride was determined by molecular absorption spectroscopy with Zirconyl - Alizarin chelate using UV-Vis T80 device (Helios) at the wavelength of $527 \mathrm{~nm}$.

\subsection{Effect of $\mathrm{pH}$}

With the aim of assessing the effect of $\mathrm{pH}$ to the fluoride adsorption, nine samples containing $100 \mathrm{~mL}$ fluoride solution were prepared with the concentration of $10 \mathrm{mg} . \mathrm{L}^{-1}$. The $\mathrm{pH}$ of samples was adjusted from 3 to 11 (with the notations of the samples were from $\mathrm{pH} 3$ to $\mathrm{pH} 11$ ), the temperature was fixed at $25{ }^{\circ} \mathrm{C}$. Each sample was stirred for 2 hours after adding RHA/Al $(\mathrm{OH})_{3}$ into the solution with the dose of $5 \mathrm{~g} . \mathrm{L}^{-1}$ in order to reach to the adsorption equilibrium. The solution was filtered and the fluoride concentration was determined. The efficient of the adsorption was calculated by the equation as follows:

$$
\mathrm{H}=\frac{\mathrm{C}_{\mathrm{o}}-\mathrm{C}_{\mathrm{e}}}{\mathrm{C}_{\mathrm{o}}} \times 100
$$

where $\mathrm{C}_{\mathrm{o}}$ and $\mathrm{C}_{\mathrm{e}}$ are the concentration of fluoride in the solution before and after adsorption, respectively $\left(\mathrm{mg} \cdot \mathrm{L}^{-1}\right)$.

\subsection{Effect of the dose of $\mathrm{RHA} / \mathrm{Al}(\mathrm{OH})_{3}$}

The suitable dose of $\mathrm{RHA} / \mathrm{Al}(\mathrm{OH})_{3}$ was chosen after investigating the efficient of the fluoride adsorption of 10 samples containing adsorbent with the dose varying from 1 to 10 g.L. $\mathrm{L}^{-1}$ 
(notations of samples were from LL1 to LL10). Other factors were fixed and the practical steps were described in 2.2 item.

\subsection{Adsorption isotherm}

The maximum fluoride adsorption capacity $\left(\mathrm{q}_{\mathrm{m}}\right)$ of $\mathrm{RHA} / \mathrm{Al}(\mathrm{OH})_{3}$ was determined by isotherm survey. Seven samples were prepared, each sample containing $100 \mathrm{~mL}$ of fluoride solution with the content rising from 5 to $35 \mathrm{mg} . \mathrm{L}^{-1}$ (the samples were notated from C5 to C35). The dose of adsorbent was fixed at $5 \mathrm{~g} \cdot \mathrm{L}^{-1}$. Other factors were fixed and the practical steps were described in 2.2 item.

In this research, the Langmuir and Freundlich isotherm models $[7,8,9,10]$ were used to evaluated the adsorption.

The Freundlich isotherm model is based on heterogeneous surfaces suggesting that binding sites are not equivalent and independent. The Langmuir isotherm model is applicable to the homogeneous adsorption where the adsorption of each adsorbate molecule onto the surface has an equal adsorption activation energy. The Freundlich and Langmuir models can be expressed as follows:

$$
\begin{aligned}
& \ln \mathrm{q}_{\mathrm{e}}=\ln \mathrm{K}_{\mathrm{F}}+\frac{1}{\mathrm{n}} \mathrm{C}_{\mathrm{e}} \\
& \frac{\mathrm{C}_{\mathrm{e}}}{\mathrm{q}_{\mathrm{e}}}=\frac{\mathrm{C}_{\mathrm{e}}}{\mathrm{q}_{\mathrm{m}}}+\frac{1}{\mathrm{~K} \times \mathrm{q}_{\mathrm{m}}}
\end{aligned}
$$

where: $\mathrm{C}_{\mathrm{e}}$ is the equilibrium concentration of fluoride in the solution after adsoption $\left(\mathrm{mg} . \mathrm{L}^{-1}\right)$; $\mathrm{q}_{\mathrm{e}}$ is adsorption amount of $\mathrm{RHA} / \mathrm{Al}(\mathrm{OH})_{3}\left(\mathrm{mg} \cdot \mathrm{g}^{-1}\right)$, that was calculated by equation: $\mathrm{q}_{\mathrm{e}}=\frac{\left(\mathrm{C}_{\mathrm{o}}-\mathrm{C}_{\mathrm{e}}\right) \mathrm{V}}{\mathrm{m}}$, where: $\mathrm{C}_{\mathrm{o}}$ is the initial concentration of fluoride $\left(\mathrm{mg} \cdot \mathrm{L}^{-1}\right), \mathrm{V}$ is the volume of fluoride solution $(\mathrm{L}), \mathrm{m}$ is the mass of $\mathrm{RHA} / \mathrm{Al}(\mathrm{OH})_{3}(\mathrm{~g}) ; \mathrm{q}_{\mathrm{m}}$ is maximum fluoride adsoprtion capacity $\left(\mathrm{mg}^{-1} \mathrm{~g}^{-1}\right) ; \mathrm{K}$ is Langmuir constant which is related to the strength of adsorption; $\mathrm{K}_{\mathrm{F}}$ and $\mathrm{n}$ is Fruendlich constants that are related to the adsorption capacity and the adsorption intensity.

\subsection{Adsorption kinetic}

The kinetics data of fluoride adsorption was obtained when the effect of time to adsorption capacity of adsorbent was investigated. $\mathrm{RHA} / \mathrm{Al}(\mathrm{OH})_{3}$ was added into $100 \mathrm{~mL}$ of $10 \mathrm{mg} . \mathrm{L}^{-1}$ fluoride solution with the dose of $5 \mathrm{~g} . \mathrm{L}^{-1}$, the temperature was fixed at $25^{\circ} \mathrm{C}$. After 10 minutes, $10 \mathrm{~mL}$ of the stirring mixture was separated and the fluoride was determined.

The pseudo-first-order rate model (4) and the pseudo-second-order rate model $(5)[7,8,10]$ was applied to test the kinetic data.

The pseudo-first-order and pseudo-second-order kinetic equations are given as:

$$
\begin{aligned}
& \ln \left(\mathrm{q}_{\mathrm{e}}-\mathrm{q}_{\mathrm{t}}\right)=\ln \left(\mathrm{q}_{\mathrm{e}}\right)-\mathrm{k}_{1} \mathrm{t} \\
& \frac{\mathrm{t}}{\mathrm{q}_{\mathrm{t}}}=\frac{1}{\mathrm{k}_{2} \mathrm{q}_{\mathrm{e}}^{2}}+\frac{\mathrm{t}}{\mathrm{q}_{\mathrm{e}}}
\end{aligned}
$$

where: $\mathrm{q}_{\mathrm{e}}\left(\mathrm{mg} \cdot \mathrm{g}^{-1}\right)$ and $\mathrm{q}_{\mathrm{t}}\left(\mathrm{mg} \cdot \mathrm{g}^{-1}\right)$ are the amount of fluoride ions adsorbed on the adsorbent at equilibrium and any time, respectively; $\mathrm{k}_{1}\left(\mathrm{~L} \cdot \mathrm{s}^{-1}\right)$ and $\mathrm{k}_{2}\left(\mathrm{~g} \cdot \mathrm{mg}^{-1} \cdot \mathrm{s}^{-1}\right)$ are the pseudo-first-order and pseudo-second-order rate constant. 


\subsection{Thermodynamic studies}

In order to understand the mechanism of adsorption, thermodynamic parameters such as $\Delta \mathrm{G}^{\mathrm{o}}, \Delta \mathrm{H}^{\mathrm{o}}$ and $\Delta \mathrm{S}^{\mathrm{o}}$ were calculated according to the study of effect of temperature to adsorption. Five groups of samples were prepared at 5 temperatures varying from $303 \mathrm{~K}$ to $343 \mathrm{~K}$. Each group including 10 samples that contained $0.5 \mathrm{~g}$ of $\mathrm{RHA} / \mathrm{Al}(\mathrm{OH})_{3}$ and $100 \mathrm{~mL}$ of fluoride solution corresponding with the initial concentration varying from 10 to $40 \mathrm{mg} . \mathrm{L}^{-1}$. The mixtures were stirred for 80 minutes until the adsorption reached equilibrium. After that, fluoride contents of separating solution were determined.

The equilibrium constant of adsorption $\left(\mathrm{K}_{\mathrm{c}}\right)$ was approximately calculated by the equation from the studies of J. Rahchamani [9]:

$$
\mathrm{K}_{\mathrm{C}}=\frac{\mathrm{C}_{\mathrm{ae}}}{\mathrm{C}_{\mathrm{e}}}=\frac{\mathrm{q}_{\mathrm{e}}}{\mathrm{C}_{\mathrm{e}}}
$$

where: $\mathrm{C}_{\mathrm{ae}}$ and $\mathrm{C}_{\mathrm{e}}$ are equilibrium fluoride concentration on the adsorbent and solution (mg. $\mathrm{L}^{-1}$ ); $\Delta \mathrm{G}^{\mathrm{o}}$ parameter of adsorption was determined by (7) equation. From the obtained results, $\Delta \mathrm{H}^{\mathrm{o}}$ and $\Delta S^{\circ}$ parameters were obtained from the correlation equation between $\ln \mathrm{K}_{\mathrm{C}}$ and $1 / \mathrm{T}$ basing on (8) equation.

$$
\begin{aligned}
& \Delta \mathrm{G}^{\mathrm{o}}=-\mathrm{RT} \ln \mathrm{K}_{\mathrm{C}} \\
& \ln \mathrm{K}_{\mathrm{C}}=-\frac{\Delta \mathrm{G}^{\mathrm{o}}}{\mathrm{RT}}=\frac{\Delta \mathrm{S}^{\mathrm{o}}}{\mathrm{R}}-\frac{\Delta \mathrm{H}^{\mathrm{o}}}{\mathrm{RT}} .
\end{aligned}
$$

\section{RESULTS AND DISCUSSION}

\subsection{Effect of pH}

Fluoride adsorption behavior of $\mathrm{RHA} / \mathrm{Al}(\mathrm{OH})_{3}$ under different $\mathrm{pH}$ was investigated to determine the optimal $\mathrm{pH}$ for removing of fluoride ions. The results are shown in Table 1.

Table 1. The influence of $\mathrm{pH}$ on fluoride removal capacity.

\begin{tabular}{|c|c|c|c|c|c|c|c|c|c|}
\hline Notations & $\mathrm{pH} 3$ & $\mathrm{pH} 4$ & $\mathrm{pH} 5$ & $\mathrm{pH} 6$ & $\mathrm{pH} 7$ & $\mathrm{pH} 8$ & $\mathrm{pH} 9$ & $\mathrm{pH} 10$ & $\mathrm{pH} 11$ \\
\hline $\mathrm{pH}$ & 3.0 & 4.0 & 4.8 & 6.0 & 7.0 & 8.0 & 9.0 & 10.0 & 11.0 \\
\hline $\mathrm{C}_{\mathrm{e}}\left(\mathrm{mg}_{\mathrm{L}} \mathrm{L}^{-1}\right)$ & 1.15 & 0.69 & 0.52 & 0.41 & 0.42 & 0.42 & 0.41 & 0.40 & 2.19 \\
\hline $\mathrm{H}(\%)$ & 88.5 & 93.1 & 94.8 & 95.9 & 95.8 & 95.8 & 95.9 & 96.0 & 78.1 \\
\hline
\end{tabular}

As can be seen in Table 1, the adsorption was well-done in the range of $\mathrm{pH}$ from 4.0 to 10.0 because the fluoride adsorption efficiencies of $\mathrm{RHA} / \mathrm{Al}(\mathrm{OH})_{3}$ were always more than $90 \%$ and unvaried, especially, from 6.0 to 10.0. Also, both of studies of Salifu [10] and Ganvir [1] expressed that the $\mathrm{pH}$ of $7.0( \pm 0.2)$ had been the suitable $\mathrm{pH}$ for fluoride removal. Therefore, the adjustment of $\mathrm{pH}$ was no need in after experiments.

\subsection{Effect of adsorbent dose}

Table 2 shows fluoride removal capacity of $\mathrm{RHA} / \mathrm{Al}(\mathrm{OH})_{3}$ with different doses at $\mathrm{pH}$ of 7.0. Table 2, it has been found that the fluoride adsorption efficiency increases from $76.7 \%$ to nearly 
$100 \%$ correspoding with the rise of adsorbent dose from 1 to $5 \mathrm{~g} . \mathrm{L}^{-1}$. It can be explained that the adsorption surface increases when the dose of material increases. From the dose of 5 to $10 \mathrm{~g} . \mathrm{L}^{-1}$, almost of fluoride was removed from the solution, so, the adsorption capacity varied unimportant. Hence, 5 g. $\mathrm{L}^{-1}$ of $\mathrm{RHA} / \mathrm{Al}(\mathrm{OH})_{3}$ was chosen as the optimum dose.

Table 2. The influence of $\mathrm{RHA} / \mathrm{Al}(\mathrm{OH})_{3}$ dose on fluoride removal capacity.

\begin{tabular}{|c|c|c|c|c|c|c|c|c|c|c|}
\hline Notations & LL1 & LL2 & LL3 & LL4 & LL5 & LL6 & LL7 & LL8 & LL9 & LL10 \\
\hline $\begin{array}{c}\text { Dose of adsorbent } \\
\left(\mathrm{g} . \mathrm{L}^{-1}\right)\end{array}$ & 1 & 2 & 3 & 4 & 5 & 6 & 7 & 8 & 9 & 10 \\
\hline $\mathrm{C}_{\mathrm{e}}\left(\mathrm{mg} . \mathrm{L}^{-1}\right)$ & 2.33 & 1.42 & 0.71 & 0.56 & 0.41 & 0.32 & 0.25 & 0.23 & 0.17 & 0.15 \\
\hline $\mathrm{H}(\%)$ & 76.7 & 85.8 & 92.9 & 94.4 & 95.9 & 96.8 & 97.5 & 97.7 & 98.3 & 98.5 \\
\hline
\end{tabular}

\subsection{Adsorption isotherm study}

The correlation between equilibrium concentration of fluoride $\left(\mathrm{C}_{\mathrm{e}}\right)$ and adsorption amount of $\mathrm{RHA} / \mathrm{Al}(\mathrm{OH})_{3}\left(\mathrm{q}_{\mathrm{e}}\right)$ was considered through isothermal adsorption study. The data acquired from experiments of 7 samples from $\mathrm{C} 5$ to $\mathrm{C} 35$ with different initial concentrations of fluoride were shown in Table 3. After that, the interaction between $\mathrm{q}_{\mathrm{e}}$ and $\mathrm{C}_{\mathrm{e}}$ was obtained from Langmuir 2 and Freundlich models. This result was expressed in Figure 1.

Table 3. The fluoride removal capacities at different initial concentrations of fluoride.

\begin{tabular}{|c|c|c|c|c|c|c|c|}
\hline Notations & C5 & C10 & C15 & C20 & C25 & C30 & C35 \\
\hline $\mathrm{C}_{\mathrm{o}}\left(\mathrm{mg} . \mathrm{L}^{-1}\right)$ & 5 & 10 & 15 & 20 & 25 & 30 & 35 \\
\hline $\mathrm{C}_{\mathrm{e}}\left(\mathrm{mg} . \mathrm{L}^{-1}\right)$ & 0.222 & 0.413 & 0.751 & 1.278 & 1.954 & 2.929 & 4.449 \\
\hline $\mathrm{q}_{\mathrm{e}}\left(\mathrm{mg} \cdot \mathrm{g}^{-1}\right)$ & 0.956 & 1.917 & 2.850 & 3.744 & 4.609 & 5.414 & 6.110 \\
\hline
\end{tabular}
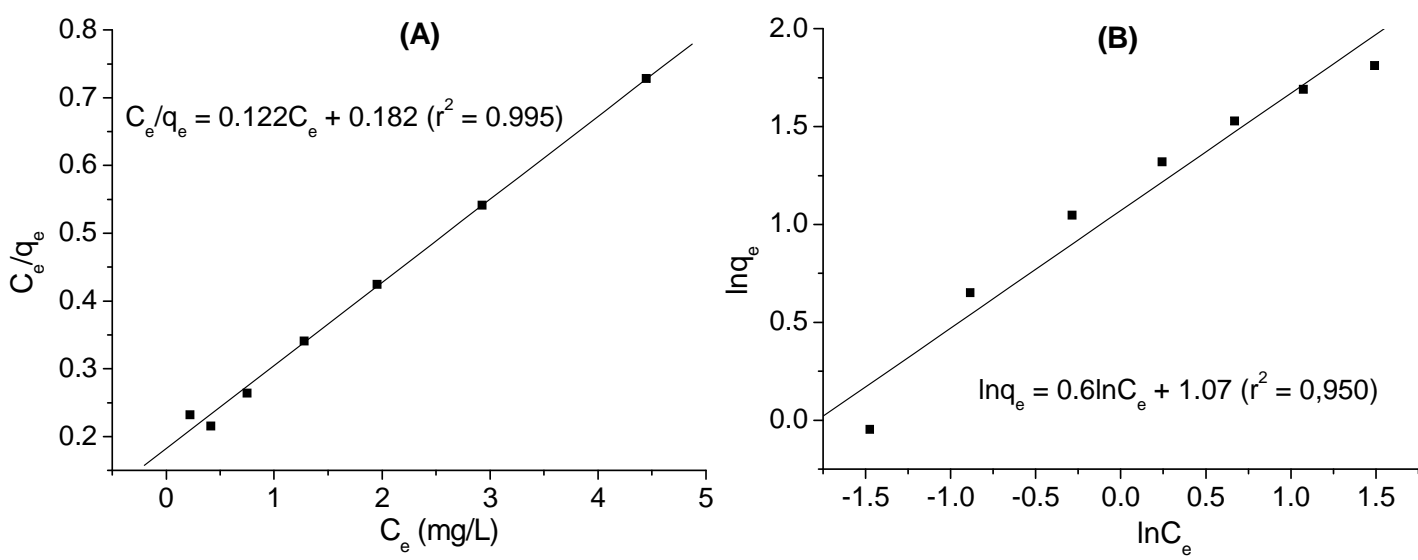

Figure 1. Linearization of the Langmuir 2 (A) and Freundlich (B) adsorption isotherm models.

As can seen, the correlation coefficient $(r)$ value of Langmuir 2 model $\left(r^{2}=0.995\right)$ was higher than that of Freundlich model $\left(r^{2}=0.950\right)$, which implied that the isotherm data were fitted to the Langmuir 2 model. Maximum fluoride adsorption capacity of material was 8.2 
mg.g ${ }^{-1}$. These results were similar to those in the study of Salifu [10]. Salifu indicated that among adsoprtion isotherm models, Langmuir 2 model exposed the highest correlation coefficient $\left(r^{2}=0.985\right)$ with the maximum fluoride adsorption capacity of $7.874 \mathrm{mg} \cdot \mathrm{g}^{-1}$. The results of Z. Qiusheng also proved the suitability of Langmuir 2 model with $r^{2}=0.968$ [11]. According to this model, the fluoride adsorption onto $\mathrm{RHA} / \mathrm{Al}(\mathrm{OH})_{3}$ is monolayer adsorption, that means the surface containing the adsorbing sites is perfectly flat plane with no corrugation, all sites are equivalent, each site can hold at most one molecule of adsorbate and there are no interactions between adsorbate molecules on adjacent sites.

\subsection{Adsorption kinetic}

In order to find the kinetic model describing well the adsortion of fluoride onto $\mathrm{RHA} / \mathrm{Al}(\mathrm{OH})_{3}$, the effect of time to the adsorption was analysed. The amount of fluoride adsorbed onto the material $\left(\mathrm{q}_{\mathrm{t}}\right)$ at different time $(\mathrm{t})$ was determined. The results were showed in Table 4. The correlation bewteen $\mathrm{q}_{\mathrm{t}}$ and $\mathrm{t}$ was obtained from these results in Figure 2 .

Table 4. The amount of fluoride adsorbed onto the material at different time.

\begin{tabular}{|c|c|c|c|c|c|c|c|c|}
\hline Notations & D10 & D20 & D30 & D40 & D50 & D60 & D70 & D80 \\
\hline $\mathrm{t}$ (mintues) & 10 & 20 & 30 & 40 & 50 & 60 & 70 & 80 \\
\hline $\mathrm{C}_{\mathrm{t}}\left(\mathrm{mg} . \mathrm{L}^{-1}\right)$ & 1.97 & 1.64 & 1.34 & 1.08 & 0.86 & 0.68 & 0.54 & 0.42 \\
\hline $\mathrm{q}_{\mathrm{t}}\left(\mathrm{mg} \cdot \mathrm{g}^{-1}\right)$ & 1.606 & 1.672 & 1.732 & 1.784 & 1.828 & 1.864 & 1.892 & 1.916 \\
\hline Notations & $\mathrm{D} 90$ & $\mathrm{D} 100$ & $\mathrm{D} 110$ & $\mathrm{D} 120$ & $\mathrm{D} 130$ & $\mathrm{D} 140$ & $\mathrm{D} 150$ & $\mathrm{D} 160$ \\
\hline $\mathrm{t}($ mintues $)$ & 90 & 100 & 110 & 120 & 130 & 140 & 150 & 160 \\
\hline $\mathrm{C}_{\mathrm{t}}\left(\mathrm{mg} . \mathrm{L}^{-1}\right)$ & 0.43 & 0.43 & 0.42 & 0.42 & 0.40 & 0.43 & 0.40 & 0.41 \\
\hline $\mathrm{q}_{\mathrm{t}}\left(\mathrm{mg} \cdot \mathrm{g}^{-1}\right)$ & 1.915 & 1.914 & 1.917 & 1.916 & 1.92 & 1.914 & 1.92 & 1.918 \\
\hline
\end{tabular}

Figure 2 showed that in the first 80 minutes, the longer time, the more fluoride adsorbed onto the material $\left(\mathrm{q}_{\mathrm{t}}\right)$. After that, the value of $\mathrm{q}_{\mathrm{t}}$ varied around $1.91 \mathrm{mg} \cdot \mathrm{g}^{-1}$ which proved that the adsorption got equilibrium.

From the reaction kinetic of pseudo-first-order and pseudo-second-order rate model, the correlation between $\ln \left(\mathrm{q}_{\mathrm{e}}-\mathrm{q}_{\mathrm{t}}\right)$ and $\mathrm{t} ; \mathrm{t} / \mathrm{q}_{\mathrm{t}}$ and $\mathrm{t}$ was expressed in Figure 3 .

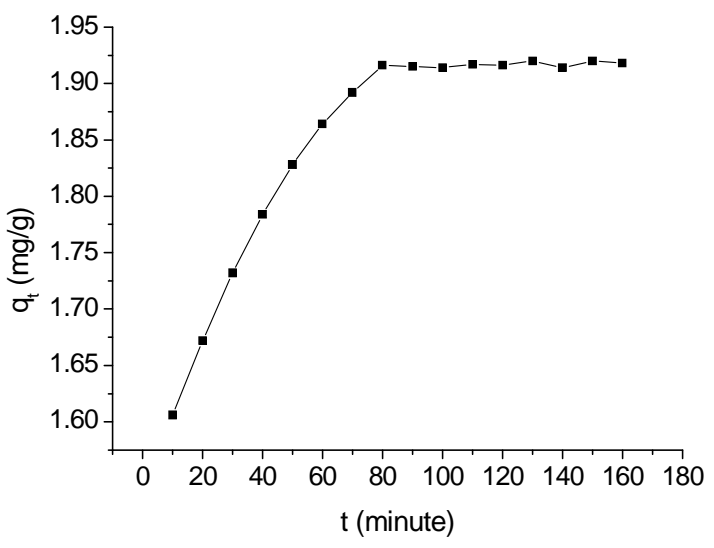

Figure 2. The relation bewteen $\mathrm{q}_{\mathrm{t}}$ and $\mathrm{t}$. 

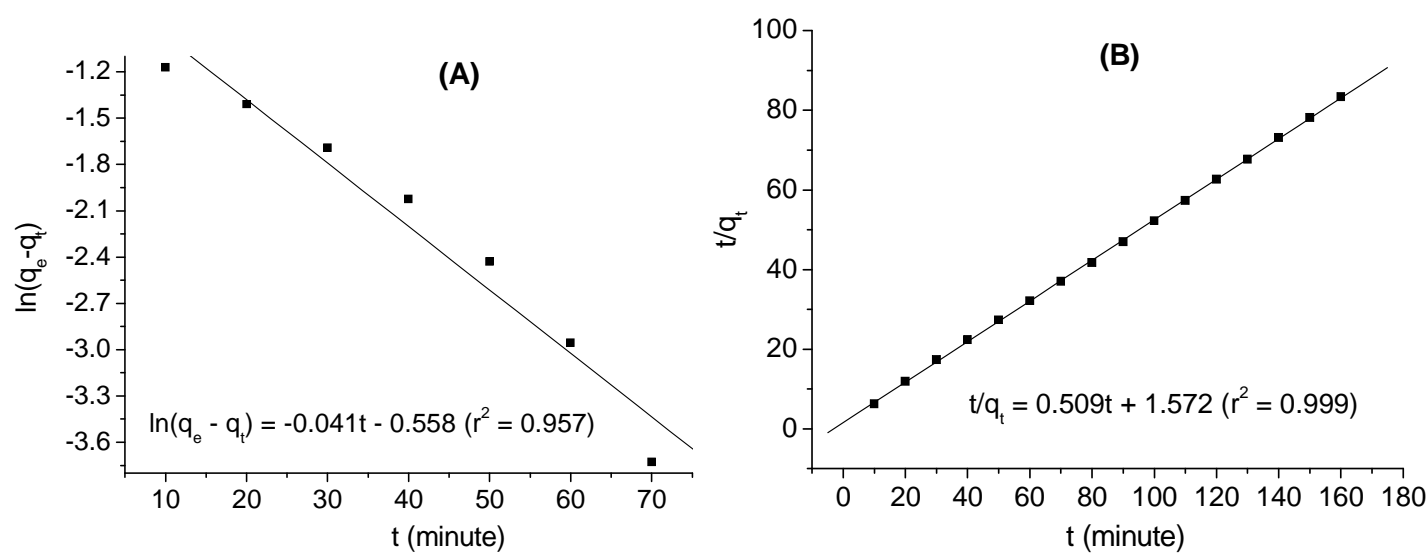

Figure 3. Pseudo-first-order model (A) and pseudo-second-order model (B) for fluoride adsorption.

The above results indicated that the adsorption of fluoride onto RHA/Al $(\mathrm{OH})_{3}$ obeyed the pseudo-second-order rate model with high correlation coefficient $\left(r^{2}=0.999\right)$. This agrees with the publication of Ganvir [1], Garcia-Sanchez [7] and Qiusheng [11].

\subsection{Thermodynamic studies}

Thermodynamic parameters of fluoride adsorption onto RHA/Al $(\mathrm{OH})_{3}$ were determined by the investigation of the effect of temperature to the amount of adsorbed fluoride in the range of temperature from $303 \mathrm{~K}$ to $343 \mathrm{~K}$. The results were represented in Table 5.

From the Figure 4, thermodynamic parameters were calculated and showed in Table 6.

Table 5. The effect of temperature to fluoride adsorption of RHA/Al(OH) $)_{3}$.

\begin{tabular}{|c|c|c|c|c|c|}
\hline \multirow{2}{*}{$\mathrm{C}_{0}\left(\mathrm{mg} . \mathrm{L}^{-1}\right)$} & \multicolumn{5}{|c|}{$\mathrm{C}_{\mathrm{e}}\left(\mathrm{mg} . \mathrm{L}^{-1}\right)$} \\
\cline { 2 - 6 } & $303(\mathrm{~K})$ & $313(\mathrm{~K})$ & $323(\mathrm{~K})$ & $333(\mathrm{~K})$ & $343(\mathrm{~K})$ \\
\hline 10 & 0.43 & 0.41 & 0.39 & 0.36 & 0.36 \\
\hline 15 & 0.82 & 0.68 & 0.63 & 0.61 & 0.60 \\
\hline 20 & 1.29 & 1.18 & 1.12 & 1.09 & 1.06 \\
\hline 25 & 2.15 & 1.94 & 1.82 & 1.69 & 1.60 \\
\hline 30 & 3.02 & 2.96 & 2.87 & 2.51 & 2.17 \\
\hline 35 & 4.50 & 4.27 & 4.02 & 3.90 & 3.88 \\
\hline 40 & 6.55 & 5.72 & 5.43 & 5.01 & 4.90 \\
\hline $\mathrm{q}_{\mathrm{m}}\left(\mathrm{mg} \cdot \mathrm{g}^{-1}\right)$ & 8.2 & 8.4 & 8.5 & 8.6 & 8.7 \\
\hline $\operatorname{lnK} \mathrm{K}_{0}$ & 1.672 & 1.754 & 1.817 & 1.868 & 1.911 \\
\hline
\end{tabular}




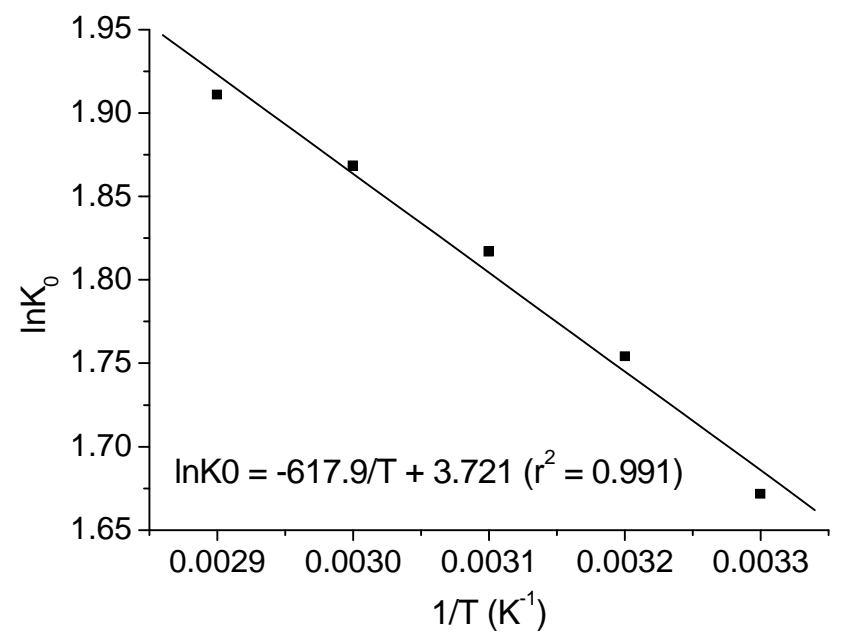

Figure 4. Van't Hoff diagram of fluoride adsorption onto RHA/Al $(\mathrm{OH})_{3}$.

Table 6. Thermodynamic parameters of fluoride adsorption onto $\mathrm{RHA} / \mathrm{Al}(\mathrm{OH})_{3}$.

\begin{tabular}{|c|c|c|}
\hline Temperature $(\mathrm{K})$ & $\Delta \mathrm{G}^{\mathrm{o}}\left(\mathrm{J} \cdot \mathrm{mol}^{-1}\right)$ & \multirow{2}{*}{$\Delta \mathrm{H}^{\mathrm{o}}\left(\mathrm{J} \cdot \mathrm{mol}^{-1}\right)$} \\
\hline 303 & -4211.53 & \\
\hline 313 & -4565.09 & \\
\cline { 1 - 2 } & \multirow{2}{*}{5137.22} \\
\hline 323 & -4879.69 & \\
\hline 333 & -5171.87 & \\
\hline 343 & -5449.63 & \\
\hline
\end{tabular}

The positive value of enthalpy $\left(\Delta \mathrm{H}^{\mathrm{o}}=+5.14 \mathrm{~kJ} \cdot \mathrm{mol}^{-1}\right)$ proved endothermic nature of fluoride adsorption, which agreed with the result that the higher temperature, the higher adsorption capacity at equilibrium state, absolutely. The chemisorption nature of the adsorption was also affirmed because of high enthalpy. The mechanism of the adsorption might be ion exchange between fluoride ion and $\mathrm{OH}^{-}$groups from $\equiv \mathrm{Al}-\mathrm{OH}$ sites [11]. In addition, the higher $\mathrm{pH}$, the higher amount of adsorbed fluoride because the $\mathrm{pH}$ of the solution was higher than 5.53 [6], the point of zero charge of material. So, an amount of fluoride was complexed strongly with $\mathrm{Al}^{3+}$ on the surface of rice husk ash. The negative value of $\Delta \mathrm{G}^{\mathrm{o}}$ at different temperatures implied that the adsorption was spontaneous.

\subsection{Treatment of fluoride in well-water}

In Khanhhoa province, the fluorosis is so popular because of high concentration of fluoride that exceeds the the acceptable limit [2]. For practical purpose, we sampled well-water at Ninhthuong commune, Ninhhoa district, Khanhhoa province. The samples that are transparent, colorless, odorless contain fluoride with the concentration of about $10.1 \mathrm{mg} . \mathrm{L}^{-1}$ (exceeds the standard of $\mathrm{WHO}$ ) and have $\mathrm{pH}$ of 8.8.

Ten samples notated from $\mathrm{H} 1$ to $\mathrm{H} 10$ were prepared. Each sample contained $100 \mathrm{~mL}$ of well-water. $\mathrm{RHA} / \mathrm{Al}(\mathrm{OH})_{3}$ was added into the sample with the dose increasing from $1 \mathrm{~g} \cdot \mathrm{L}^{-1}$ to 10 g.L. ${ }^{-1}$. The samples were stirred for 2.0 hours in order to reach to adsorption equilibrium. The 
concentration of fluoride after adsorption were determined $\left(\mathrm{C}_{\mathrm{e}}\right)$. The results were showed in Table 7.

Table 7. Fluoride adsorption efficiency of $\mathrm{RHA} / \mathrm{Al}(\mathrm{OH})_{3}$ in well-water.

\begin{tabular}{|c|c|c|c|}
\hline Notations & $\begin{array}{c}\text { Dose of material } \\
\left(\mathrm{g} . \mathrm{L}^{-1}\right)\end{array}$ & $\begin{array}{c}\mathrm{C}_{\mathrm{e}} \\
(\mathrm{mg} . \mathrm{L})\end{array}$ & $\begin{array}{c}\mathrm{H} \\
(\%)\end{array}$ \\
\hline $\mathrm{H} 1$ & 1 & 3.48 & 65.5 \\
\hline $\mathrm{H} 2$ & 2 & 2.40 & 76.2 \\
\hline $\mathrm{H} 3$ & 3 & 1.72 & 83.0 \\
\hline H4 & 4 & 1.13 & 88.8 \\
\hline H5 & 5 & 0.76 & 92.5 \\
\hline H6 & 6 & 0.63 & 93.8 \\
\hline H7 & 7 & 0.57 & 94.4 \\
\hline H8 & 8 & 0.49 & 95.1 \\
\hline H9 & 9 & 0.45 & 95.5 \\
\hline H10 & 10 & 0.31 & 96.9 \\
\hline
\end{tabular}

The above results indicate that the fluoride adsorption ability of $\mathrm{RHA} / \mathrm{Al}(\mathrm{OH})_{3}$ in wellwater is well. With the dose of material from 4.0 g. $\mathrm{L}^{-1}$ to $7.0 \mathrm{~g} . \mathrm{L}^{-1}$, the fluoride concentration decreases under the acceptable limit of WHO $\left(0.5-1.5\right.$ g.L $\left.\mathrm{L}^{-1}\right)$ that is useful for the development of teeth and bond. Well-water after treatment is colorless, odorless, has $\mathrm{pH}$ of 7.65 and can be used as running water.

\section{CONCLUSION}

$\mathrm{RHA} / \mathrm{Al}(\mathrm{OH})_{3}$ containing $20 \% \mathrm{Al}_{2} \mathrm{O}_{3}$ could adsorbed fluoride ion in aqueous solution with the maximum adsorption capacity of $8.2 \mathrm{mg}^{-1} \mathrm{~g}^{-1}$. The adsorption capacity was depended on the solution $\mathrm{pH}$ and the adsorbent dose. The adsorption data could be well-described by Langmuir 2 model and the adsorption kinetic followed the pseudo-second-order model. The positive enthalpy $\left(\Delta \mathrm{H}^{\circ}=+5.14 \mathrm{~kJ} / \mathrm{mol}\right)$ proved that the chemisorption predominated. This material could well adsorb fluoride in well-water that contained high content of fluoride. After treatment with the dose of material of $4.0-7.0$ g.. $\mathrm{L}^{-1}$ for 2 hours, the concentration of fluoride was decreased from around $10.1 \mathrm{mg} . \mathrm{L}^{-1}$ to $0.5-1.5 \mathrm{~g} . \mathrm{L}^{-1}$ that was fit for the acceptable limit of WHO.

\section{REFERENCES}

1. Ganvir V., Das K. - Removal of fluoride from drinking water using aluminum hydroxide coated rice husk ash, Journal of Hazardous Materials 185 (2011) 1287-294.

2. Hoang Trong Sy, Nguyen Trong Liem - Study of timeless fluoride poisoning on teeth of people at Ninhhoa - Khanhhoa and development of the process of fluoride treatment in well-water, The $5^{\text {th }}$ national meeting of sciences-Association of Vietnam public medical, 2009, pp. 122-132. 
3. Jimenez-Reyes M., Solache-Rios M. - Sorption behavior of fluoride ions from aqueous solutions by hydroxyapatite, Journal of Hazardous Materials 180 (2010) 297302.

4. Meenakshi S., Sundaram C.S., Sukumar R. - Enhanced fluoride sorption by mechanochemically activated kaolinites, Journal of Hazardous Materials 153 (2008) pp. 164-172.

5. Tor A., Danaoglu N., Arslan G., Cengeloglu Y. - Removal of fluoride from water by using granular red mud: Batch and column studies, Journal of Hazardous Materials 164 (2009) 271-278.

6. Tran Ngoc Tuyen, Luu Thi Luong, Tran Minh Ngoc, Vu Thuan Trung - Study on the synthesis of aluminium hydroxide coated rice husk ash using removal fluoride in aqueous solution, Vietnam Journal of Catalysis and Adsorption 4 (2) (2015) pp. 139-144.

7. Garcia-Sanchez J. J., Martinez-Miranda V., Solache-Rios M. - Aluminum and calcium effects on the adsorption of fluoride ions by corrosion products, Journal of Flouride Chemistry 145 (2013) 136-140.

8. Islam M., Patel R.K. - Evaluation of removal efficiency of fluoride from aqueous solution using quick lime, Journal of Hazardous Materials 143 (2007) 303-310.

9. Rahchamani J., Mousavi H. Z., Behzad M. - Adsorption of methyl violet from aqueous solution by polyacrylamide as an adsorbent: isotherm and kinetic studies, Desalination 267 (2011) 256-260.

10. Salifu A., Petrusevski B., Ghebremichael K., ModestusL., Buamah R., Aubry C., Amy G.L. - Aluminum (hydr)oxide coated pumice for flouride removal from drinking water: Synthesis, equilibrium, kinetics and mechanism, Chemical Engineering Journal 228 (2013) 63-67.

11. Qiusheng Z., Xiaoyan L., Bin L., Xuegang L. - Flouride adsorption from aqueous solution by aliminum alginate particles prepared via electrostatic spinning device, Chemical Engineering Journal 256 (2014) 306-315.

\title{
TÓM TÁ̀T
}

\section{NGHIÊN CÚU ĐỘNG HỌC VÀ NHIÊT ĐỘNG CỦA QUÁ TRÌNH HÂP PHỤ ION FLORUA TRONG DUNG DICH NƯỚC LỂ VẬT LIỆU TRO TRÂUU PHỦ NHÔM HIDROXIT}

\author{
Trần NgọcTuyền ${ }^{1, *}$, Nguyễn Đức Vũ Quyên ${ }^{1}$, Hồ Văn Minh Hải ${ }^{1}$, \\ Trần Ngọc Quang ${ }^{2}$, Hoàng Trọng Sỹ $\tilde{y}^{3}$, Nguyễn Trọng Liêm ${ }^{4}$ \\ ${ }^{I}$ Khoa Hóa, Trưòng Đại hoc Khoa hoc Huê, 77 Nguyễn Huệ, Huế \\ ${ }^{2}$ Khoa Môi truờng, Truờng Đại học Khoa học Huế, 77 Nguyễn Huệ, Huế \\ ${ }^{3}$ Truoòng Đại học Y Dược Huế, O6 Ngô Quyền, Huế \\ ${ }^{4}$ Trung tâm Y tế huyện Ninh Hòa, tỉnh Khánh Hòa \\ "Email: trntuyen@gmail.com
}


Khả năng hấp phụ ion florua trong dung dịch nước bằng vật liệu tro trấu phủ nhôm hydroxit $\left(\mathrm{RHA} / \mathrm{Al}(\mathrm{OH})_{3}\right)$ đã được khảo sát trong nghiên cứu này. Kết quả nghiên cứu đẳng nhiệt cho thấy mô hình đẳng nhiệt hấp phụ Langmuir mô tả tốt bản chất của quá trình hấp phụ với dung lượng hấp phụ cực đại đạt $8,2 \mathrm{mg} / \mathrm{g}$. Đây là quá trình hấp phụ hóa học, tốc độ hấp phụ tuân theo phương trình động học hấp phụ bậc hai biểu kiến. Khảo sát ảnh hưởng của nhiệt độ đến dung lượng hấp phụ trong khoảng nhiệt độ từ 30 đến $70^{\circ} \mathrm{C}$ cho thấy quá trình hấp phụ là tự diễn biến và thu nhiệt. Vật liệu $\mathrm{RHA} / \mathrm{Al}(\mathrm{OH})_{3}$ có khả năng xử lý rất tốt các mẫu nước giếng trong thực tế có nồng độ ion florua cao. Với các mẫu nước giếng tại huyện Ninh Hòa (Khánh Hòa) có nồng độ ion florua $10,1 \mathrm{mg} / \mathrm{L}$, sau khi xử lí với liều lượng vật liệu hấp phụ từ 4,0 đến $7,0 \mathrm{~g} / \mathrm{L}$, sau thời gian 2 giờ, nồng độ ion florua trong nước giếng sau khi xử lí đạt từ $0,5-1,5 \mathrm{~g} / \mathrm{L}$, thoả mãn tiêu chuẩn của WHO.

Tù khóa: vật liệu tro trấu phủ nhôm hidroxit, hấp phụ, florua. 